\title{
Speculations on biting midges and other bloodsucking arthropods as alternative vectors of Leishmania
}

\author{
Veronika Seblova', Jovana Sadlova', Simon Carpenter ${ }^{2}$ and Petr Volf ${ }^{*}$
}

\begin{abstract}
Sand flies remain the only proven vectors of Leishmania spp. but recent implementation of PCR techniques has led to increasing speculation about "alternative vectors", including biting midges. Here, we summarize that PCR has considerable limits for studing the role of bloodsucking arthropods in the epidemiology of leishmaniasis. The Leishmania life cycle in the sand fly includes a complex series of interactions which are in many cases species-specific, the early phase of the infection is, however, non-specific to sand flies. These facts should be considered in detection of Leishmania in ,"alternative" or "new" vectors to avoid mistaken speculation about their vector competence.
\end{abstract}

Keywords: Culicoides, Phlebotomus, Leishmania

\section{Correspondence}

Slama et al. [1] recently published a report in Parasites and Vectors on the discovery of Leishmania infantum DNA in two bloodfed Culicoides species, Culicoides imicola and C. circumscriptus. While this demonstrates that Culicoides feed on hosts infected with L. infantum in Tunisia, they also extend this to suggesting biological transmission of the pathogen. In doing so, they repeatedly support their speculation by referring to our work, Seblova et al. [2] published in the Journal of Medical Entomology. Quoting directly, they state that Seblova et al. [2] "had proved the susceptibility of C. nubeculosus to L. infantum infection". This is unfortunate as a directly opposite conclusion was reached in our paper, we demonstrated that the population of $C$. nubeculosus tested did not support development of L. infantum and L. major and hence the probability of this species acting as a vector of Leishmania species infecting humans was negligable. Therefore, we would like to react and avoid misleading other readers.

The implication of alternative vectors of Leishmania parasites, like ticks, fleas and biting midges, in the

\footnotetext{
* Correspondence: volf@cesnet.cz

'Department of Parasitology, Faculty of Science, Charles University in Prague, Prague 2128 44, Czech Republic

Full list of author information is available at the end of the article
}

transmission cycle of Leishmania parasites is repeatedly discussed in the literature. The role of the brown dog tick, Rhiphicephalus sanguineus, was investigated in relation to the epidemiology of canine leishmaniasis caused by L. infantum [3-5] but its significance remains uncertain. Similarly, biting midges of subgenus Forcipomyia (Lasiohelea) were incriminated as vectors of $L$. enrietti complex causing cutaneous leishmaniasis in red kangoroos [6] but this parasite-vector relationship differed significantly from that studied by Slama et al. [1]. Other Leishmania were PCR-detected even in non-parasitic insects; the finding of Leishmania tarentolae in sarcophagid fly can be explained by licking a wound of an injured gecko [7].

The Leishmania life cycle in the vector gut includes several morphological forms and a complex series of interactions which are in many cases species-specific [8]. There are several natural barriers, like proteolytic enzymes, the peritrophic matrix and sand fly immune molecules, all of which require adaptation in the Leishmania promastigotes to overcome. As blood digestion proceeds, Leishmania needs to bind to midgut epithelium to avoid being excreted with bloodmeal remnants. In natural vectors they then migrate forwards, attach to the stomodeal valve and transform to infective metacyclic forms [8]. The early phase of infection in the vector is, 
however, non-specific; almost any Leishmania survive and divide within the sand fly bloodmeal, even in members of the genus Sergentomyia, but they thrive only till defecation [9].

Similarly, in experimentally infected Culicoides nubeculosus Seblova et al. (2012) demonstrated that Leishmania major and L. infantum developed only early-stage infections and then they are defecated with bloodmeal remnants. Interestingly, the PCR assay detected parasite DNA post-defecation, until day 7 post-infection, despite the microscopical examination revealing that at this time point there were no living parasites. These observations correspond to the study of Coutinho et al. [10] or Paz et al. [4] where PCR detection of Leishmania DNA was accompanied by microscopical observation. Although the PCR assay detected Leishmania DNA, no viable Leishmania promastigotes were identified. These results cannot be interpreted simply by lower detection threshold of microscopical techniques. Myskova et al. [11] quantified Leishmania parasites in experimentally infected sand flies before and after bloodmeal defecation by quantitative PCR and two "traditional" methods, estimation in situ and direct counting with the aid of hemocytometer. No significant differences were found between microscopical observation in situ and Q-PCR after the bloodmeal was passed. Rather, it is necessary to note that the presence of the amplification products does not imply that target organisms were viable due to the persistance of DNA after cell death. This fact should be considered particularly in PCR detection of parasites in "alternative" or "new" vectors to avoid mistaken speculation about their vector competence.

We are aware that recent spread of PCR techniques broadly available to laboratories with little experience in vector aspects of parasite life cycles has led to an increasing number of speculations about "new" vectors. As highlighted by Seblova et al. [2], PCR has considerable limits for studing the role of bloodsucking arthropods in the epidemiology of leishmaniasis. Microscopical observation of Leishmania morphological stages in invertebrates, however, remains the gold standard of detection enabling assessment of localization in the gut at different time points post-bloodmeal. At present, therefore, phlebotominae sand flies should remain the only proven biological vectors of Leishmania species infecting humans until convincing evidence is provided to the contrary.

\section{Competing interest}

The authors declare that they have no competing interests.

\section{Authors' contributions}

VS wrote the initial draft. All authors read and approved the final manuscript.

\section{Acknowledgements}

All authors are supported by FP7-261504 EDENext and the manuscript is cataloged as EDENext 221.

\section{Author details}

1 Department of Parasitology, Faculty of Science, Charles University in Prague, Prague 2128 44, Czech Republic. ${ }^{2}$ Institute for Animal Health (IAH), Pirbright, Surrey GU24 ONF, UK.

Received: 6 March 2014 Accepted: 5 May 2014

Published: 14 May 2014

\section{References}

1. Slama D, Haouas N, Remadi L, Mezhoub H, Babba H, Chaker E: First detection of Leishmania infantum (Kinetoplastida: Trypanosomotidae) in Culicoides spp. (Diptera: Ceratopogonidae). Parasit Vectors 2014, 7:51.

2. Seblova V, Sadlova J, Carpenter S, Volf P: Development of Leishmania parasites in Culicoides nubeculosus (Diptera: Ceratopogonidae) and implications for screening vector competence. J Med Entomol 2012, 49:967-970

3. Dantas-Torres F, Lorusso V, Testini G, Paiva-Cavalcanti M, Fiqueredo LA Stanneck D, Mencke N, Brandao-Filho SP, Alves LC, Otranto D: Detection of Leishmania infantum in Rhipicephalus sanguineus ticks from Brazil and Italy. Parasitol Res 2010, 106:857-860.

4. Paz GF, Ribeiro MFB, Michalsky EM, da Rocha Lima ACVM, Franca-Silva JC, Barata RA, Fortes-Dias CL, Dias ES: Evaluation of the vectorial capacity of Rhipicephalus sanguineus (Acari: Ixodidae) in the transmission of canine visceral leishmaniasis. Parasitol Res 2010, 106:523-528.

5. Solano-Gallego L, Rossi L, Scroccaro AM, Montarsi F, Caldin M, Furlanello T, Trotta M: Detection of Leishmania infantum DNA mainly in Rhipicephalus sanguineus male ticks removed from dogs living in endemic areas of canine leishmaniasis. Parasit Vectors 2012, 5:98.

6. Dougall AM, Alexander B, Holt DC, Harris T, Sultan AH, Bates PA, Rose K, Walton SF: Evidence incriminating midges (Diptera: Ceratopogonidae) as potential vectors of Leishmania in Australia. Int J Parasitol 2011, 41:571-579.

7. Týč J, Votýpka J, Klepetková H, Suláková H, Jirků M, Lukeš J: Growing diversity of trypanosomatid parasites of flies (Diptera: Brachycera): frequent cosmopolitism and moderate host specificity. Mol Phylogenet Evol 2013, 69:255-264.

8. Dostálová A, Volf P: Leishmania development in sand flies: parasite-vector interactions overview. Parasit Vectors 2012, 5:276. Review.

9. Sádlova J, Dvořák V, Šeblová V, Warburg A, Votýpka J, Volf P: Sergentomyia schwetzi is not a competent vector for Leishmania donovani and other Leishmania species pathogenic to humans. Parasit Vectors 2013, 6:186.

10. Coutinho MT, Bueno LL, Sterzik A, Fujiwara RT, Botelho JR, De Maria M, Genaro O, Linardi PM: Participation of Rhipicephalus sanguineus (Acari: Ixodidae) in the epidemiology of canine visceral leishmaniasis. Vet Parasitol. 2005, 128:149-155.

11. Myskova J, Votypka J, Volf P: Leishmania in sand flies: comparison of quantitative polymerase chain reaction with other techniques to determine the intensity of infection. J Med Entomol 2008, 45:133-138.

doi:10.1186/1756-3305-7-222

Cite this article as: Seblova et al:: Speculations on biting midges and other bloodsucking arthropods as alternative vectors of Leishmania. Parasites \& Vectors 2014 7:222

\section{Submit your next manuscript to BioMed Central and take full advantage of:}

- Convenient online submission

- Thorough peer review

- No space constraints or color figure charges

- Immediate publication on acceptance

- Inclusion in PubMed, CAS, Scopus and Google Scholar

- Research which is freely available for redistribution 